LOZERAND, Emmanuel (dir.) - Drôles d'individus. De la singularité individuelle dans le Reste-du-monde

Josep Martí

\title{
OpenEdition
}

Journals

Édition électronique

URL : http://journals.openedition.org/etudesafricaines/20643

DOI : 10.4000 /etudesafricaines. 20643

ISSN : $1777-5353$

Éditeur

Éditions de l'EHESS

Édition imprimée

Date de publication : 1 avril 2017

Pagination : 198-200

ISBN : 978-2-7132-2688-5

ISSN : 0008-0055

Référence électronique

Josep Martí, « Lozerand, Emmanuel (dir.) - Drôles d'individus. De la singularité individuelle dans le Restedu-monde », Cahiers d'études africaines [En ligne], 225 | 2017, mis en ligne le 01 avril 2017, consulté le 24 septembre 2020. URL : http://journals.openedition.org/etudesafricaines/20643 ; DOI : https:// doi.org/10.4000/etudesafricaines.20643

Ce document a été généré automatiquement le 24 septembre 2020.

(C) Cahiers d'Études africaines 


\section{LOZERAND, Emmanuel (dir.) - Drôles d'individus. De la singularité individuelle dans le Reste-du-monde}

Josep Martí

\section{RÉFÉRENCE}

LOZERAND, Emmanuel (dir.) - Drôles d'individus. De la singularité individuelle dans le Restedu-monde. Paris, Klincksieck (« Continents philosophiques »), 2014, 568 p., bibl.

1 This collective work brings together an interdisciplinary anthology of stimulating texts, which were mostly presented in seminars held throughout the year 2008 in Paris by the Institut National de Langues et Civilisations Orientales (Inalco). The aim of those seminars, as is also the case for this book, was to reflect on the issue of the individual beyond the Western conception. The basic impetus was to overcome the view that aprioristically understands non-Western societies as "holistic," conveniently, without taking into account the reality of the individual and related processes of individuation. In this book, edited by Emmanuel Lozerand, specialists-chiefly from the fields of sociology, linguistics, political science, anthropology, philosophy, history and literature-present a total of 37 contributions.

Laroussi Amri, in his article on the individual in the Maghreb, begins his text by saying that an assessment of studies about the individual in the present-day Maghreb would classify people into two different categories: those who use the term "individual" loosely, that is, as one which might be substituted, replaceable by others such as "person," "man," "being," "subject," etc. and those, actually much less numerous, who are more faithful to a strictly sociological conceptualisation. The same can be said in reference to this volume in general, something that is, for the most part, unavoidable because of the different academic traditions of the authors. However, this by no means implies that the book lacks interest. 
3 The book is divided into six sections. The first one provides a good introduction to the issue by means of dense and well-crafted theoretical contributions by Emmanuel Lozerand, Danilo Martuccelli, Kathya Araujo, Christian Le Bart and Philippe Corcuff. The authors are specialists whose previous work on conceptual aspects of individuation is perfectly reflected in their texts in this volume. These authors start with the idea that one should avoid the simplistic line of thinking according to which certain cultures are considered as more or less individualistic, without nuancing all the distinctions that we find in different societies. Indeed, analysis and criticism concentrate on the claim that the West invented the individual, making it one of the leading and exclusive traits of Western civilisation and the idea that there would have been no individual before modernity and outside of the West. This very presupposition is precisely what would prevent us from recognising individuals in other cultural contexts. Christian Le Bart, in his contribution to the book, speaks of individualisation as the "great narrative myth" or "Grand Récit" of Western societies.

The second section of the book focuses philosophical and religious conceptions of the individual. The articles in this section present examples from the chinese, Tibetan, Japanese and Jewish traditions. It is in the third section of the book where we find contributions of potential interest to Africanists. Under the heading "Anthropological and linguistic approaches, among the various texts," Jean-Luc Ville's article, "Individu et individualisme en Afrique," focuses on "holistic" societies, using examples of African traditional culture with the aim of providing some ideas about individualism from the anthropological point of view. He bases his analysis on the concept of altruism/ selfishness, as it appears in examples the author takes from witchcraft beliefs and oral literature. Another contribution from this section of the book that also addresses African contexts is Odile Racine-Issa's article "La notion de personne chez les Swahili de Zanzibar. Esquisse d'un portrait d'ombres et de lumière." Within the field of knowledge of linguistics, the author, in the first part of the article, approaches the issue of individuality in Swahili society through personal name giving and kinship terminology, and in the second part, describes the individual understood as a site which is affected by difficult-to-control influences, sensations, feelings and drives which belong to the world of diseases and emotions.

5 The fourth section of the book, which is devoted to the historical development of individualism, contains two articles that provide data on the Maghreb, especially the text written by Laroussi Amri, "L'individu au Maghreb aujourd'hui." An interesting article, the author posits a typology of the individual in the Maghreb according to a major or minor detachment from his/her community of origin. This correlates directly with differences between people inhabiting coastal areas or interior areas of the country and also coincides with individuals' greater or lesser Westernisation. According to the author, greater possibilities of economic, political or cultural exchange, available in coastal areas, facilitate processes of individualisation. People residing on the coast live their individualisation as emancipation from ancestral ties. The article by Catherine Mayeur-Jaouen, "Individu et famille en islam: des conceptions médiévales aux réalités contemporaines," although it focuses on Islam in general, makes some allusions to the Maghreb. The author presents a historical sketch of the individual within family relationships. Her purpose is to deconstruct determined clichés that lead to an essentialist reification of the family in Islam which ignores the individual. Catherine Mayeur-Jaouen describes the practices of individuation such as 
they appear in historical sources, mainly biographical dictionaries, paediatric methods, ethical treatises and hagiographies.

The last two sections of the book are made up of contributions from the field of literature: "The Individual in Writing" and "Literary Expressions of Individuality." These texts are concerned with literary productions from European and Asian areas, with the exception of the article written by Xavier Garnier on "Personnage et principe d'individuation dans le roman africain." Garnier is interested in the African novel written in colonial times, following the hypothesis that the novel operates in the preindividual dimension where the principles of individuation-in the sense of Gilbert Simondon ${ }^{38}$-are produced.

7 By way of conclusion, the book ends with a substantial article by François Flahault, an anthropologist whose previous studies have already concentrated on the issue of the individual. In this text, he emphasises the fact that concrete forms of individualisation always depend on specific cultural contexts and that it is not possible to draw a clear distinction between holism and individualism, an idea that, by the way, often appears throughout the book.

Occasionally, while reading the book, one gets the impression that an opposition implicitly appears between the "Western individual" versus the "non-Western individual." Actually, there is, in and of itself, a clearly ethnocentric opposition since there is no non-Western individual-we only have to compare the African to the Asian cases presented throughout this publication-and even to talk about a "Western individual" means not taking into account the historical contingency of the individual. However, through the different contributions in this book, there is a constant and resolute will to claim the reality of the individual beyond the modern Western model, the need to overcome the Western "Grand Récit" on individualisation, and to give up considering it as a Western privilege. It is obvious that to make a rigorous comparative study of the individual in different cultures would require a systematic approach that this book cannot afford; it should not be forgotten that the book is a regrouping of various contributions previously presented in different seminar sessions. Nonetheless, as a result of these meetings, the contents of the publication have an unquestionable value and interest for future research.

\section{NOTES}

38. G. SIMONDON, L'individuation psychique et collective, Paris, Aubier Montaigne, 1989. 